\title{
The cultural transformation of Government Spending Through Money Follow Program Budget Planning for The Allocation of Village Funding
}

\author{
Taufik Kurniawan \\ \{tk.taufikkurniawan@gmail.com\} \\ Diponegoro University, Jl.Prof. H. Soedarto, S.H. Tembalang, Tembalang, Kota Semarang, Jawa \\ Tengah, 50275, Indonesia
}

\begin{abstract}
Village funding allocation increases drastically in two years, making the spending of government also increases. This drastic change gives positive hopes to fulfill society's need, which cannot be supplied by a bigger scale of development. Empirically, the budget allocation of village funding needs to be developed by money follow the program as the alternative in the budget planning system. The participative approach of society becomes an integral part of village development. Four elements need to be considered in development are the environment, process design, mechanisms, and goals\&outcomes. The institutional corroboration becomes the critical factor. There should be a budget planning management for vertical synchronization and the strengthening of society's facilitation with massive village funding simultaneously. Tiered control is centralized in the regency/city level by optimizing the function of control in the district level. This management of control is done by utilizing the technology of information and communication, which has been applied in several regencies. The institutional support from Bappenas (National Development Planning Agency) is by making technical guidance to transform works effectively.
\end{abstract}

Keywords: Government Spending, Money Follow Program, Village Funding, Budget Planning

\section{Introduction}

The village is the smallest autonomous region in a government; the village is the territory of the district government, which is under the sub-district and headed by one by the village head. Rural areas are generally characterized by low population density, agricultural land use, and relatively low levels of excellence. Therefore, in general, the welfare of the rural population is relatively low compared to urban areas, and there is a stigma that rural tends to be backward. In line with Lipton and Moore that the village studies tradition, dominated by economists, but not exclusively so, was a valuable, empirically-based alternative to other economic analyses of rural situations [5]. Government efforts to pay attention to rural areas from year to year always exist. However, due to the overwhelming number of villages and vast areas, rural development is generally relatively lagging behind the urban areas. Government action in line with Ellis stated, that concerned with stimulating non-agricultural activities in rural areas with a variety of social and economic goals in view [6].

Bappenas (National Development Planning Agency) reviewed the Evaluation of Village Development in the Context of Society's Welfare Improvement in 2011. The review noted some problems regarding village development including (1) the limit of alternative quality job fields and weak connection between economic activities in sectoral or spatial sector, (2) low 
level of infrastructure services in the village, (3) the improvement of natural resources and environmental degradation, (4) weak institution and organization for community basis, and (5) weak coordination in cross-sector in the rural area development. This evaluation is done in the relation of Program Nasional Pemberdayaan Masyarakat (PNPM) or National Program of Community Empowerment, especially for the village area. Dwyer and Childs state that development may also influence the visual character of the landscape over substantial areas. Depending on topography, a particular development may alter the view from several essential vantage points across the landscape [9].

Rural development is a part of efforts to improve the quality of society as a whole which is carried out continuously based on the potential and ability of the village itself refers to the achievement of development goals that is to realize the life of an independent, advanced, prosperous and fair society which includes all the development activities that take place in the village covering the whole aspects of community life. Wang stated that there is a problem in rural area residents, such as had some primary education only [7]. In order to accelerate rural development, it has been and will continue to be carried out various programs and activities related to improving prosperity, poverty reduction, human resource quality improvement and community involvement in the process of rural development management.

The needs for village development are getting stronger as the increasing gap of development between urban and rural areas. Therefore, in the government period of 20152019 , the effort to increase the focus in the village is realized by improving the allocation of development funding there. This is in line with $\mathrm{Li}$ and Wei research about Chinese central government that has paid more attention to solving economic polarization and endorsing programs to alleviate inequality between regional and urban-rural disparities in the last decade [12]. This effort is the part of the government's application of money follows the program. This model is applied since the previous model; the money follows function, which is no longer relevant. This model is the result of the transformation of local autonomy program. The experience of the reformation in development planning has decreased the energy of the planners and executors. Thus, there should be a reformation of budgeting and funding policy of the development which is relevant to the current situation and condition.

\section{Problem}

The acceleration and equity of development have 1-2 years left to go. Thereby, there should be a development in budgeting and control mechanism based on the change of development orientation. A quite significant change happens to village level funding with the existence of Village Funding Allocation. It has been increased significantly from 2016. Therefore, the problems of budgeting are an essential thing to build and develop. This research aims to dig the information and comprehensively understand those problems as well as to arrange the solution.

\section{3. literature review}

Regarding this research, village development has correctly been executed from the previous governance through Program Nasional Pemberdayaan Masyarakat (PNPM) or National Program of Community Empowerment. PNPM for village area consists of PNPM Mandiri Pedesaan (Independent Village), PNPM Pedesaan (for Village), PNPM Lingkungan Mandiri Pedesaan or Independent Village Environment (PNPM-LMP), and PNPM Mandiri 
Infrastruktur Pedesaan or Independent Village Infrastructure. Other empowerment programs are through PNPM, which is not explicitly focused on the village; however, there is a chance of coping village area. These kind of PNPM are R2PN (Rehabilitasi dan Rekonstruksi Pulau Nias/ Rehabilitation and Reconstruction of Nias Island), PNPM Mandiri Agribisnis/SADI (SmallholderAgribusiness Development Initiative), PNPM Generasi Sehat Dan Cerdas (Health and Smart Generation),Program Pengembangan Sistem Pembangunan Partisipatif or Participative Development System (P2SPP), and PNPM Mandiri Respek (Rencana Strategies Pengembangan Kampung or Strategic Plan for Village Development) for Papuan Community, PNPM Mandiri Perkotaan (Independent City), Pengembangan Infrastruktur Sosial Ekonomi Wilayah(PISEW) or Social Economy Infrastructure Development, ProgramPenyediaan Air Minum Berbasis Masyarakat (PAMSIMAS) or Program of Drinking Water Supply for the Society, PNPM-Mandiri Daerah Tertinggal Dan Khusus/Percepatan Pembangunan Daerah Tertinggal Dan Khusus (P2DTK) for Remote and Special Area and the Acceleration of Development to Remote and Special Area, PNPM Mandiri Kelautan Dan Perikanan (PNPM Mandiri-KP) for Fishermen, PNPM-Mandiri Pariwisataor Independent Tourism, and PNPMMandiri Perumahan dan Permukiman (PNPM-Mandiri Perkim) or for Residential Housing.

The used platform in village development is based on society's participation. They can participate in all cycles of development, starting from the planning, the execution, and the control. In line with Chambers opinion, rapid and participatory rural appraisal approaches were added to the repertoire, expanding the range of methods and styles of field engagement [1]. Regarding the focus of analysis, the number of Village Funding Allocation and Money Follow Program will result in essential participative budgeting.Sutiyo, \&Maharjan stated that to improve the effectiveness of participatory budgeting in Indonesia, there should be a mechanism whereby district governments share local budget information with the community [11].

Ebdon and Franklin, state four elements along with their variables for budgeting based on society's participation as follows.[2]

\begin{tabular}{|c|c|}
\hline ELEMENTS & VARIABLES \\
\hline Environment & $\begin{array}{ll}\text { - } & \text { Structure and form of government } \\
\text { - } & \text { Political culture } \\
\text { - } & \text { Population size and diversity }\end{array}$ \\
\hline Process Design & $\begin{array}{l}\text { Timing } \\
\text { Type of budget allocation (by a program of earmark funds, } \\
\text { operating, capital) } \\
\text { - Participants (selection methods, numbers, representativeness) } \\
\text { - Sincere preference/ willingness to pay }\end{array}$ \\
\hline Mechanisms & $\begin{array}{l}\text { - Public meetings } \\
\text { - } \text { Socus groups } \\
\text { - } \text { Adviations } \\
\text { - Surveys committees }\end{array}$ \\
\hline Goals\&Outcomes & $\begin{array}{l}\text { - Reduce cynicism } \\
\text { - } \text { Educate participants about the budget } \\
\text { - } \text { Gather input for decision making } \\
\end{array}$ \\
\hline
\end{tabular}




\begin{tabular}{|l|l|}
\hline - & Change resource allocation \\
- & Enhance trust \\
\hline
\end{tabular}

In Indonesia, especially in the case of infrastructure development in the village, participation is a critical approach. The thing which should be strengthened is the institutional aspect. It is also stated in Asnudin's research that infrastructure development project in the village will be more effective in supporting the community and village area's development if it is followed by a robust institutional program of the society and also the increase of society's economy to improve their welfare [3]. It also considers the development of infrastructure in society (waste management, water tank protection, etc.).

\section{Methodology}

Research object: the development of budget planning in the village area.Data and Technique of Analysis: Technique of Analysis used in this research is descriptive constructive analyzing the situation and condition of the object and using the information to arrange a solution for the problem. The financial data of village financial funding in the period of 20132016 were collected. The analysis of village financial condition was done by observing the changes in improvement, composition, and its distribution in Indonesia. It was done to portray the understanding regarding information of the financial situation. The other data and information were the references and related literature to understand the general problems in reconstructing or arranging the budgeting and planning in the village area.

\section{Finding}

\subsection{The ImprovementofVillage Area}

Between 2014 and 2016, budget planning for the village experienced a high increase. The spending increased to an average of $104.7 \%$. Indirect spending increased at a lower level of 27\%. The direct increase came from Village Funding Allocation with an average growth of $75.8 \%$. Direct spending, which was 14.4 trillion rupiahs in 2014, increased four times in 2016 to became 57.2 trillion along with the increasing Village Funding Allocation from 10.2 trillion to 29.4 trillion rupiahs.

Table 1.

Village Expenditure and Village Fund Allocation 2014-2016 (Rp.M)

\begin{tabular}{|l|c|c|c|}
\hline \multicolumn{1}{|c|}{ Description } & $\mathbf{2 0 1 4}$ & $\mathbf{2 0 1 5}$ & \multicolumn{1}{c|}{$\mathbf{2 0 1 6}$} \\
\hline Direct Shopping & 14.366 & 36.016 & 57.181 \\
\hline Indirect Shopping & 11.257 & 13.774 & 18.128 \\
\hline VillageFundAllocation & 10.242 & 22.847 & 29.349 \\
\hline
\end{tabular}

Source: Village Financial Statistics 
Figure 1.The trend of Shopping and Allocation of Village Funds

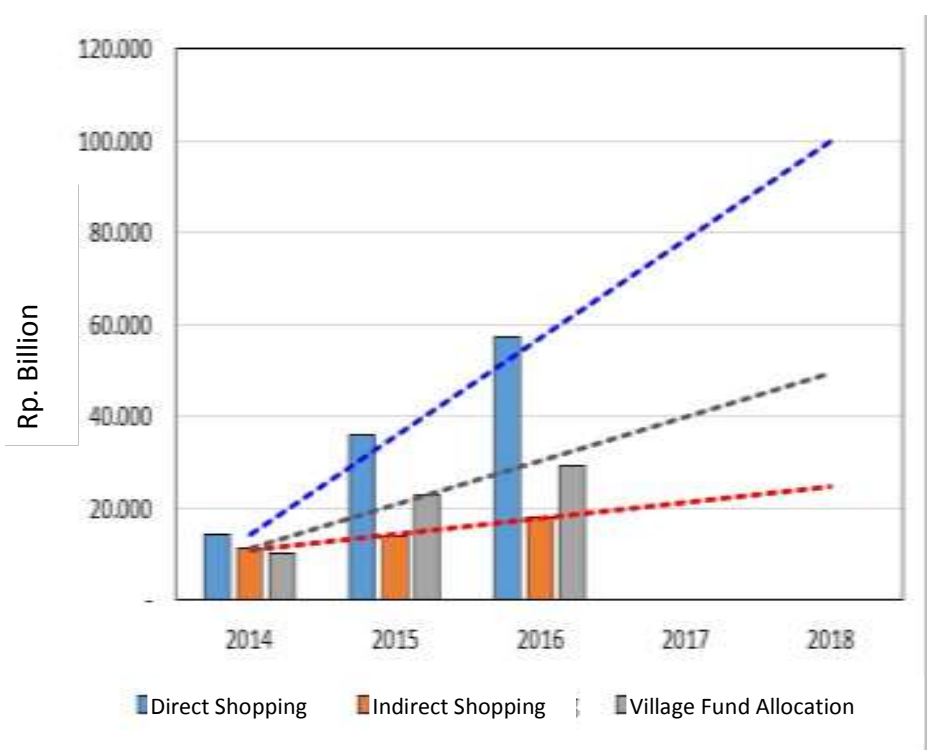

Based on the data in 2014-2016, the potential of direct spending in medium-terms will increase sharply as well as to Village Funding Allocation. This tendency creates the consequence of the development progressed by the government, especially in the synchronization of development management and organization culture. Also, regulations insist that at least 70 percent of village funds must be allocated to development activities and a maximum of 30 percent may be spent on salaries and administrative costs. Lewis stated that districts are responsible for guaranteeing that these spending conditions are met [10].

Due to the diversity and length of the area, heterogeneity of Indonesia's area becomes an important consideration Java is an island which has denser population than another area which influences the management of budgeting to villages inside. Based on the average village spending in a specific province, provinces can be grouped based on the total of spending in 2016 and the growth of spending in the period of 2014-2016. For the province with high average spending (exceeding the average spending of the village in the nation) and high growth, the needs of advanced budget planning become an obligation.

Generally, there is a balance between provinces with high spending total but having low growth or province with lower spending than the average spending of overall villages in the country. There is no province which has a high total of spending and high growth of the economy. There are no villages in the provinces that are high, and the growth is also high. These data indicate that the pattern of village income increase is relatively proportional. 
Figure 2.Quadrant Value and growth of village expenditure by the province in 2014-2016

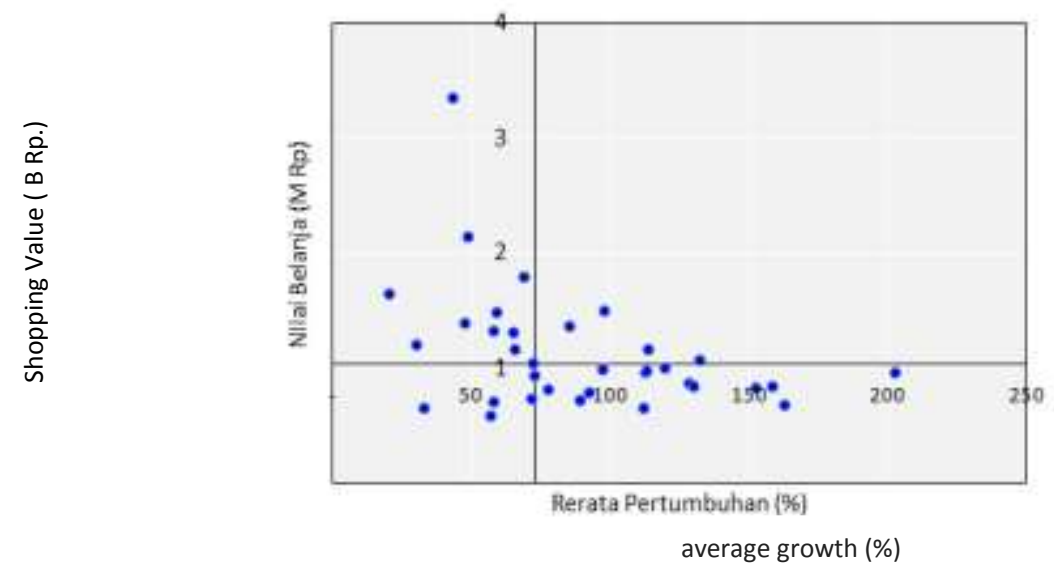

Table 2.Value Classification and Rural Expenditure Growth by Province, the Year 2014- 2016

\begin{tabular}{|l|l|l|l|}
\hline $\begin{array}{c}\text { Great Value } \\
\text { Growing High }\end{array}$ & \multicolumn{1}{c|}{$\begin{array}{c}\text { Great Value } \\
\text { Growing Low }\end{array}$} & \multicolumn{1}{|c|}{$\begin{array}{c}\text { Small Value } \\
\text { Growing High }\end{array}$} & $\begin{array}{c}\text { Small Value } \\
\text { Growing Small }\end{array}$ \\
\hline - Sumatera Barat & - Riau & - Aceh & - Sumatera Selatan \\
- NTB & - Kep. Bangka & - Sumatera Utara & - Sulawesi \\
- Kalimantan Tengah & Belitung & - Jambi & Tenggara \\
- Kalimantan Selatan & - Kep. Riau & - Bengkulu & - Papua Barat \\
& - Jawa Barat & - Lampung & - Papua \\
& - Jawa Tengah & - Banten & \\
& - DI Jogyakarta & - NTT & \\
& - Jawa Timur & - Kalimantan Barat & \\
& - Bali & - Sulawesi Utara & \\
& - Kalimantan & - Sulawesi Tengah & \\
& - Timur & - Sulawesi Selatan & \\
& - Kalimantan Utara & - Gorontalo & \\
& & - Sulawesi Barat & \\
& & - Maluku & \\
& & - Maluku Utara & \\
\hline
\end{tabular}

Source: Village Financial Statistics

Villages in West Sumatera, West Nusa Tenggara, Central Kalimantan, and South Kalimantan have high spending and growth where they need the keen ability to manage the economy. For other areas with high spending, they will have the complexity of budget planning. The high increase of budget will cause unreadiest of the village apparatuses shown by the cultural shock.

The government even planned to raise village funds from $\mathrm{Rp} 60$ trillion to $\mathrm{Rp} 120$ trillion in 2018. The increase in village funds is aimed at building and strengthening infrastructure to support the economy of the villagers. Rural Infrastructure Development Program is a rural infrastructure development assistance program directed to encourage the improvement of the rural economy. 


\subsection{The Strengths and Weaknesses of Village Spending Increase}

Regarding the fast growth of income and spending in the future, there are some strengths and weaknesses that will be faced by the village. The strengths will be as follows.

a. The insignificant funding number to the village will be handled directly by the village. It is a way to fulfill local needs based on the situation and condition of the area. Thus, the potential for significance will be experienced quickly.

b. The villages will be able to know and handle the sector, which becomes the leverage for the development in the village.

c. The difference of needs platform in national, province, regency/city, district, to village level, is the difference. Therefore, the direct allocation of spending will decrease the friction or optimize the lack of needs from locals which cannot be fulfilled directly as requested to a higher level of government.

d. The funds for the political transaction can overcome as the funding and no longer becomes the legislative or executive political service.

Some lacks or problems which might be faced are as follows.

a. The readiness of society and apparatuses in the village in terms of mechanism of planning, fulfilling technical standards, and the supply.

b. Inharmonious local activity to the aim of development in the higher administrative area.

c. It can become a potential cause of moral hazard to the apparatus or society which cooperates to the apparatus in utilizing the budget; thus, there will be a distortion to the development.

d. In the situation of uncertainty and worry of managing the funds, the allocation will not be used optimally.

e. In the broader area of the village with many activities, the apparatus will have difficulty in controlling the activities.

f. In regency/city, even national level, the monitoring and controlling of the activity tends to be complicated and cumbersome, since, the small events are spreading.

\subsection{The Need for Planning and Controlling}

In terms of budget utilization, the strengths and weaknesses in the management section need the solution. This need is to develop a comprehensive and reliable system. This need is divided into three parts:

1. Needs for Budget Planning Management:

a. Budgeting patterns. The vertical synchronization of spending allocation. Spending orientation from a different level of government (central, province, regency/city, district, village) will have different characteristics making it cannot be built partially. The synchronization will improve the synergy, decrease overlapping, and crowding out. The guidance and mechanism to this need have existed through the mechanism of National Discussion of Development orMusyawarahPerencanaan Pembangunan (Musrenbang). However, the orientation of money following programs need to review those mechanisms.

b. The strengthening of society's participation. The patterns of society's participation should be strengthened as the value of funding support will be more distributed to society. The vast spending will become an essential stimulant for society.

2. Needs for Event Control Management:

a. The needs of events control in the village done tiered in district level. The district government monitors the events as they also approve the events or only observe. 
Next, the data and information from the district are compiled in regency/city level as also figured to give technical advisory for developing villages.

b. In order to face problems of many events and distribution of it, besides the limit of human resources and unit of a worker in the area of regency/city, the mid-term also need the building of technology of information and communication to control the event as to plan it. For the references, the use of this technology refers to the experience of Banyuwangi's Government, which develop it for the aspect of development and coordination. Banyuwangi's government developed the system as a smart kampung program. Many administrative matters in this village can be done online. According to the head of the regency, Abdullah Azwar Anas, this innovation is the part of his effort to upgrade the management of the government to update the public service in the village.

3. The needs of money follow program strengthening. This model is the alternative in the budgeting and planning system for the development of the village. In line with Neely et al. opinion that aid money was spent in different ways, new people with different values and skills were hired, and, for once, even if grossly inadequately, local contexts were better understood and poor, marginalized people were involved in plans and decisions [4]. For the execution, it needs instructive support through National Development Planning Agency or Bappenas to the government through Unit of Region Work orSatuanKerjaPerangkat Daerah (SKPD) to strengthen the district and implement it further to the village to manage Village Funding Allocation. This agency needs to make technical guidance to transform works effectively.

\section{Conclusion}

The allocation of village funding increases drastically in two years. Thus, the allocation of direct or development spending also growth. This drastic change gives positive impact to fulfill society's need in the lacks which cannot be fulfilled by the higher government well. Vogt and Maran's state that growth is attributed, in part, to the attractiveness of the natural and social environments, access to good transportation and schools, and financial advantages [8]. Besides, this change also gives negative impact, which can distort the purpose of the development. Therefore, there should be a management of planning to the budget for the vertical synchronization and strengthening of the facility to the society. It needs vast funding as the stimulant. The tiered control is centralized in regency/city with optimizing the control function in the district. This management control can be done by using the technology of information and communication, which has been implemented in some regencies. The institutional support from Bappenas can be through the creation of technical guidance to transform works effectively.

\section{References}

[1] R. Chambers, Revolutions in development inquiry. London: Earthscan, 2008

[2] C.EbdonandA.Franklin, "Citizen Participation in BudgetingTheory," PublicAdministrationReview,2006,May.

[3] A. Asnudin, "Pembangunan Infrastruktur Perdesaan dengan Pelibatan masyarakat Setempat “,Jurnal SMARTek, vol. 7, No. 4,2009.

[4] C. Neely, K. Sutherland, and J. Johnson. "Do sustainable livelihoods approaches have a positive impact on the rural poor?" A look at twelve case studies. Livelihoods Support 
Programme Paper, 16. Rome: FAO. 2004.

[5] Lipton, M., and M. Moore. The methodology of village studies in less developed countries. Brighton: IDS, University of Sussex. 1972.

[6] F. Ellis, "Household strategies and rural livelihood diversification."Journal of Development Studies, Vol. 35, No, 1, p. 1-38. 1998

[7] Y. P. Wang, Y. Wang, \&J. Wu, "Urbanization and Informal Development in China: Urban Villages in Shenzhen.” International Journal of Urban and Regional Research, Vol. 33, No. 4,957-973.2009.

[8] C.A.Vogt, , R.W. Marans, "Natural resources and open space in the residential decision process: a study of recent movers to fringe counties in Southeast Michigan." Landscape Urban Plan. Vol. 69, 2004. p. 255-269.

[9] J. F., Dwyer, \&G. M. Childs, "Movement of people across the landscape: a blurring of distinctions between areas, interests, and issues affecting natural resource management." Landscape and Urban Planning, Vol. 69, No. 2-3. p.153-164. 2004

[10] B. D. Lewis, "Decentralising to Villages in Indonesia: Money (and Other) Mistakes." Public Administration and Development, No. 35, Vol. 5, p. 347-359. 2015,

[11] Sutiyo, \& K. L Maharjan. "Participatory Budgeting: Between Procedures and Realities.” Decentralization and Rural Development in Indonesia,. p.77-87. 2017

[12] Li YR, D. Y. H.Wei, "The spatial-temporal hierarchy of regional inequality of China." Applied Geography, Vol. 30, No. 3 p.303-316. 2010 